https://doi.org/10.22364/htqe.2021.03

\title{
CHANGES IN TEACHERS AND STUDENTS' PERCEIVED SCHOOL CLIMATE THROUGH THE IMPLEMENTATION OF THE SOCIAL EMOTIONAL LEARNING PROGRAM: A LONGITUDINAL STUDY
}

\author{
Sabine Berzina, Baiba Martinsone \\ University of Latvia, Latvia
}

\begin{abstract}
The aim of the study is to investigate changes in teachers' perceived school climate in the first and second years of implementing the social emotional learning (SEL) program in schools, as well as to investigate differences in $3^{\text {rd }}$ - to $6^{\text {th }}$-grade students' perceived school climate. In the two years of this study, 64 teachers participated in the SEL program alongside a control group. In the first year, teachers received training on the implementation of school-level SEL and received ready-made lesson plans for the direct practice of social and emotional skills in the classroom. In the second year, the SEL teachers were divided into two subgroups, where 32 teachers received additional supervision during the implementation. In the first year, 138 students from $3^{\text {rd }}$ to $6^{\text {th }}$ grade participated in the SEL program alongside a control group. In the second year of SEL implementation, $2233^{\text {rd }}$ to $6^{\text {th }}$ grade students participated in the program where teachers received regular supervision, and 244 students continued the SEL implementation process without changes. Georgia School Climate Survey Suite personnel, elementary and middle/high school forms were used to measure teachers' and students' perceived school climate. The results show that in both the first and second years, overall perceived school climate results were higher for both SEL teacher groups compared to the control teacher group. After the first year, students in grades 5 to 6 showed better mental health results. In the second year, only those $5^{\text {th }}$ to $6^{\text {th }}$ grade students whose teachers received regular supervision showed better mental health results. Starting from the second SEL year, both SEL $3^{\text {rd }}$ - to $4^{\text {th }}$-grade student groups showed higher perceived school climate compared to the control group. The results did not change during the second year, which indicates that the Latvian SEL primarily improves mental health results for $5^{\text {th }}$ to $6^{\text {th }}$-grade students and overall perceived school climate for $3^{\text {rd }}$ to $4^{\text {th }}$-grade students starting from the second SEL year. Ongoing support for teachers also stimulates better outcomes in mental health.
\end{abstract}

Keywords: gender, school climate, social emotional learning, students, teachers. 


\section{Introduction}

There is a general understanding that the development of $21^{\text {st-century }}$ skills should be addressed and supported in the educational process, as this will help the individual to function successfully in school, society and work environments (Jones et al., 2019). The ability to be aware of oneself and one's emotions, to regulate emotions, and to solve problems falls under the umbrella term "social emotional competence," which helps people to be successful in all areas of life (Durlak et al., 2011; Greenberg et al., 2017). The development of social emotional competence takes place in different environments and in different situations throughout life, and this process is called social emotional learning, or SEL (Collaborative for Academic, Social, and Emotional Learning [CASEL], 2003). The word "learning" is deliberately included in the term to emphasize that these skills and attitudes are formed as a process that takes place in many settings, including schools. Students spend a significant part of their day at school, and therefore school has a special role in helping develop this competence (Weissberg et al., 2015). Research shows that not all children have sufficient social emotional competence and positive behavioral skills when they start school (Gilliam \& Shahar, 2006).

The leading SEL model is offered by CASEL, which defines it as a process in which various skills, knowledge and attitudes are acquired and applied to form a healthy identity, deal with one's emotions, achieve significant goals, be empathetic to others, and be able to build and maintain supportive relationships with others. This learning process is part of one's education, which promotes academic equity, helps to establish trusting relationships between school, family, students and society, and provides meaningful learning content and instructions as well as evaluations of the learning process. SEL also helps to address inequalities and build a school and surrounding environment in which everyone can thrive (CASEL, 2020).

The way in which social emotional competence is most often promoted is through the implementation of SEL programs in schools. These programs promote the development of cognitive, affective and behavioral competencies (Durlak et al., 2011). Most outcomes of an SEL program are positively affected by four aspects (Schonert-Reichl, 2011; Mahoney et al., 2020).

First, the program should directly ensure the development of students' social emotional competence by defining specific skills to be developed and practiced in the classroom in a sequential, age-appropriate manner, where students take an active part in learning (Durlak et al., 2011). Direct skill development is typically related to the five core skill model offered by CASEL (Weissberg et al., 2015). 
Second, programs should ensure the development of teachers' social emotional skills and provide ongoing learning opportunities on how to provide a positive learning context, how to use teaching instructions to develop the most positive student behaviors and attitudes and relationships, and how to implement SEL in the best possible way (O'Conner et al., 2017; Mahoney et al., 2020). Regular supportive supervision that is directly related to the SEL teaching experience helps teachers implement the program with fidelity and effectively address SEL issues in the classroom (Denham et al., 2012).

The third important aspect is a wide implementation of the program, from the classroom and school level to the involvement of parents and society (Weissberg et al., 2015). The fourth aspect is to evaluate the outcomes of the program regularly.

Research shows that in cases where SEL programs are well-implemented in schools, positive outcomes can be achieved shortly thereafter, and the risk of problem development can be reduced at the pre-school, primary and secondary school levels; positive outcomes such as better mental health can also be observed in the long term (Weissberg et al., 2015). The positive benefits of SEL programs are better academic performance, better interpersonal relationships, and reduced emotional regulation problems (Weaver \& Wilding, 2013). After the implementation of SEL, the general climate in the classroom also improves (Durlak et al., 2011).

\section{School climate}

Current research shows that the school climate and SEL are inseparable processes that affect each other (Osher \& Berg, 2017). A supportive and safe school climate promotes the development of a student's social emotional skills and vice versa - more socially emotionally competent students and teachers promote a more favorable school climate (Barbarasch \& Elias, 2009).

The school climate is an indicator of the quality of school life based on the daily school experiences of students, parents and teachers (Thapa et al., 2013). It reflects common social norms, values and goals, the quality of relationships, teaching and learning experiences, prosocial behavior, and the organizational school environment (National School Climate Council, 2007). A more positive school climate is associated with lower non-attendance and exclusion from school and greater attachment to school, as well as greater motivation and involvement in the learning process on the part of students, and thus academic achievements are also higher (Reyes et al., 2012). It is also associated with an emotional and physical sense of security at school, positive personal development, and healthy relationships with peers and teachers (Thapa et al., 2013). In Latvia, better perceived security 
and connectedness to teachers and peers are associated with better mental health outcomes for students (La Salle et al., 2021).

\section{Latvian SEL program}

The Latvian SEL program, called "Social-emotional learning. Lesson plans for grades 1-12" (Martinsone et al., 2021), is a universal and preventive school-wide program from $1^{\text {st }}$ to $12^{\text {th }}$ grade. It consists of five topics, set according to five SEL skill groups - understanding yourself, managing yourself, understanding others, building relationships, and making responsible decisions. There are two age-appropriate 40-minute lessons for each topic, giving a total of 10 practical SEL lessons per academic year. The SEL program has a plan for each lesson and thus follows a unified structure.

The SEL program has two main goals: 1 ) to directly develop social emotional skills and 2) to promote a holistic approach to lesson management, setting an important goal for students by providing positive, growth-oriented feedback during lessons, reflecting on what knowledge and skills have been acquired, and ensuring students' self-assessment of what they have learned.

This study suggests that although it is clear that the school climate and SEL are interlinked, there needs to be an investigation to obtain a more detailed understanding of the relationship, given that the school climate is a multidimensional construct (Osher \& Berg, 2017).

The support provided to teachers affects the strategies they use in the classroom and the fidelity of SEL implementation (O'Conner et al., 2017). We argue that more support for teachers should create a more positive classroom climate, which has been suggested by other researchers (Schonert-Reichl, 2017) but has not been investigated directly.

This study hypothesizes that in the first and second years of its implementation, teachers and students who participate in the SEL program will show a higher perceived school climate compared to the control group. In the second year, teachers and students who received regular SEL supervision will score higher in the school climate survey than those who did not, and no change will be observed in the control group.

\section{Method}

\section{Participants}

During the two years of the SEL program's implementation, 90 teachers participated in the research. In the first year, there were a total of 64 SEL schoolteachers and 26 control schoolteachers. In the second year, the 64 SEL teachers were divided into two subgroups: 32 received regular supervision (SuperSEL group), and 32 continued the implementation 
of SEL without change (SEL basic group). The 26 teachers in the control group remained unchanged. In addition, in the first year, there were 271 participating students from grades 3 to 6,138 of whom were in the SEL group and 133 in the control group. In the second year, 641 students participated, of whom 223 were students from the SuperSEL group, 244 were students from the SEL basic group, and 174 were control group students.

\section{Procedure}

In the first year (school year 2017/2018), data were collected as part of a cross-cultural initiative to adapt the Georgia School Climate Survey Suite (GSCS Suite; La Salle et al., 2016) to the Latvian context. SEL training was given in seven Latvian schools. A two-hour on-site workshop explained what the SEL program is and how to implement it. Teachers acquired in-depth knowledge on SEL during 16 hours of training on self-directed learning and social emotional learning, provided by the School2030 project. During this first year, schools were divided into two groups: schools that started implementing the SEL program and control schools, which validated the school climate survey but did not implement the SEL program. In the second year (school year 2018/2019), the total sample of 64 SEL teachers was randomly divided into two subsamples. 32 teachers received regular on-site supervision (SuperSEL group) led by the first author of this study once every six weeks. In total, four supervisions were provided for each SuperSEL school. During each 2-hour supervision, questions on how best to exercise social emotional competence both in the classroom and outside, how to form more positive relationships, and how to overcome obstacles regarding the implementation of the program were discussed. The remaining 32 teachers continued to implement SEL without changes (SEL basic group). The control group schools remained the same during both years. Data were collected from December 2017 to June 2019.

\section{Measures}

The GSCS Suite's forms for school personnel, elementary students ( $3^{\text {rd }}$ - and $4^{\text {th }}$-grade), and middle/high school students ( $5^{\text {th }}$ - and $6^{\text {th }}$-grade) were used (La Salle, McIntosh \& Eliason, 2016, adapted in Latvian by B. Martinsone). Both sets of student forms include demographic questions regarding grade and gender. The elementary form has 11 statements on overall perceived school climate, and the middle/high school form has 36 statements about different aspects of the school climate (school connectedness, character, physical environment, adult social support, peer social support, cultural acceptance, order and discipline, and safety), with eight additional questions on mental health. The school personnel forms measured different aspects of the school climate (school connectedness, structure for 
learning, school safety, physical environment, peer/adult relations, and parental involvement).

\section{Data analysis}

In the first year of the SEL program's implementation, in order to determine the differences in perceived school climate between the SEL teacher and control teacher groups and SEL students and the control student group, a non-parametrical statistical method, the Mann-Whitney $U$ test, was used. In the second year, when differences were determined between three groups of teachers and students, a non-parametrical method, the Kruskal-Wallis $H$ test, was used with a post-hoc Mann-Whitney $U$ test with Bonferroni correction. In non-parametrical statistics, the one possibility to control for changes in time is to calculate a subtraction between the latter measurement and the first measurement, and those subtraction results are then used to compare the groups. This method was used in this research to control for changes in time. Statistical analyses were conducted using SPSS version 22 .

\section{Results}

To test the hypothesis that there are statistically significant differences between teacher groups in perceived school climate measurements controlling for time between the end of the first year of SEL implementation (measurement no. 2) and the end of the second year of SEL implementation (measurement no. 3), the differences between the second and first measurements and between the third and first measurements were calculated, and these difference measures were compared between teacher groups (see Table 1).

The hypothesis that teachers who implemented the SEL program would show a higher perceived school climate was confirmed. At the end of the first year, there are statistically significant differences between SEL teacher group subtraction results $(\mathrm{Md} n=1)$ and control group subtraction results $(\mathrm{Md} n=0)$ in the overall perceived school climate $\mathrm{U}\left(\mathrm{N}_{\mathrm{SEM}} 54, \mathrm{~N}_{\text {control }} 23\right)=449.5, \mathrm{z}=-1.94, \mathrm{p}=0.053$. There are also statistically significant differences between the SEL and control groups' subtraction results on the school climate subscale physical environment $\mathrm{U}=521.5, \mathrm{z}=-2.84, \mathrm{p}=0.004$, with the SEL group showing higher results $(\mathrm{Md} n=0)$ than the control teacher group ( $\mathrm{Md} n=0)$.

The hypothesis that teachers who received regular supervision in the second year of the SEL program would score higher in the school climate survey than those who implemented the SEL program without regular supervision was partly confirmed. 
Table 1. Differences in perceived school climate descriptive and concluding statistics between $2^{\text {nd }}$ and 1 st measurements for SEL total teacher and control teacher group and differences between $3^{\text {rd }}$ and $1^{\text {st }}$ measurements for two SEL teacher subgroups (SuperSEL, SEL basic training) and control teacher groups.

\begin{tabular}{|c|c|c|c|c|c|c|c|c|c|}
\hline \multicolumn{9}{|c|}{$M(S D)$} & \multirow[t]{2}{*}{$H / U$} \\
\hline $\begin{array}{l}\text { School } \\
\text { climate }\end{array}$ & $n$ & Total SEL & $n$ & Control & $n$ & SuperSEL & $n$ & SEL basic & \\
\hline $\begin{array}{l}\text { School } \\
\text { climate }_{\text {sum }} 2-1\end{array}$ & 54 & $2.7(7.32)$ & 23 & $0(0.56)$ & & & & & u449.5* \\
\hline $\begin{array}{l}\text { School } \\
\text { climate }_{\text {sum }} 3-1\end{array}$ & & & 23 & $-3(4.54)$ & 30 & $3.1(6.92)$ & 24 & $3.6(4.83)$ & ${ }^{\mathrm{H}} 20.516^{* * *}$ \\
\hline \begin{tabular}{|l} 
Staff \\
connectedness \\
$2-1$
\end{tabular} & 60 & $0.4(2.42)$ & 23 & $0(0.66)$ & & & & & U622.5 \\
\hline $\begin{array}{l}\text { Staff } \\
\text { connectednes } \\
3-1\end{array}$ & & & 23 & $-1(1.85)$ & 31 & $1(2.3)$ & 30 & $-0.1(1.38)$ & H $13.820^{* * *}$ \\
\hline $\begin{array}{l}\text { Structure for } \\
\text { learning 2-1 }\end{array}$ & 62 & 0.5 (2.29) & 26 & $0(0.77)$ & & & & & U702 \\
\hline $\begin{array}{l}\text { Structure for } \\
\text { learning 3-1 }\end{array}$ & & & 26 & $-1.2(2)$ & 32 & $0.6(1.62)$ & 30 & $0.7(1.82)$ & H4.975 \\
\hline $\begin{array}{l}\text { School safety } \\
2-1\end{array}$ & 60 & $-0.2(1.85)$ & 26 & $-0.4(0.75)$ & & & & & U656.5 \\
\hline $\begin{array}{l}\text { School safety } \\
3-1\end{array}$ & & & 26 & 0.4 (1.35) & 31 & $0.7(1.62)$ & 29 & $0.2(1.42)$ & $\mathrm{H} 0.444$ \\
\hline $\begin{array}{l}\text { Physical } \\
\text { environment } \\
2-1\end{array}$ & 63 & $0.5(1.1)$ & 26 & $-0.2(0.9)$ & & & & & U $521.5^{* * *}$ \\
\hline $\begin{array}{l}\text { Physical } \\
\text { environment } \\
3-1\end{array}$ & & & 26 & 0 (1.37) & 32 & $-0.3(2.14)$ & 31 & 0 (1.13) & $\mathrm{H} 0.271$ \\
\hline \begin{tabular}{|l} 
Peer/adult \\
relations 2-1
\end{tabular} & 60 & $1.2(2.64)$ & 26 & $\begin{array}{l}0.34 \\
(0.68)\end{array}$ & & & & & U592.5 \\
\hline \begin{tabular}{|l} 
Peer/adult \\
relations 3-1
\end{tabular} & & & 26 & $-0.5(2.99)$ & 31 & $1.3(1.67)$ & 29 & $1.3(2.15)$ & H9.136" \\
\hline \begin{tabular}{|l} 
Parental \\
involvement \\
$2-1$
\end{tabular} & 64 & $0.3(1.46)$ & 26 & $0.7(0.39)$ & & & & & u 74.5 \\
\hline $\begin{array}{l}\text { Parental } \\
\text { involvement } \\
3-1\end{array}$ & & & 26 & $-1(1.41)$ & 32 & $0.2(2)$ & 32 & $0.1(1.23)$ & $\mathrm{H} 10.13^{* *}$ \\
\hline
\end{tabular}


The results show no significant difference between both SEL groups, and both SEL groups show higher perceived school climate results compared to the control group. There are statistically significant differences in overall perceived school climate subtraction results between the three groups $\mathrm{H}(2)=20.516, p=0.000$. The post-hoc Mann-Whitney $\mathrm{U}$ test indicated differences between the SuperSEL ( $\mathrm{Md} n=1.5$ ) and control group ( $\mathrm{Md} n=-3$ ) subtraction results $\mathrm{U}\left(\mathrm{N}_{\text {supersem }} 30, \mathrm{~N}_{\text {control }} 23\right)=151.00, z=-3.49, \mathrm{p}=0.000$ and between the SEL basic ( $\mathrm{Md} n=3$ ) and control group ( $\mathrm{Md} n=-3$ ) subtraction results $\mathrm{U}\left(\mathrm{N}_{\text {sembasic }} 24, \mathrm{~N}_{\text {control }} 23\right)=70.5, z=-4.38, p=0.000$.

There are statistically significant differences between the groups for the school climate subscale staff connectedness $\mathrm{H}(2)=13.820$, $p=0.001$. The post-hoc test indicated significant differences between the SuperSEL ( $\mathrm{Md} n=0$ ) and control group ( $\mathrm{Md} n=-1$ ) subtraction results $\mathrm{U}\left(\mathrm{N}_{\text {supersem }} 31, \mathrm{~N}_{\text {control }} 23\right)=164.5, z=-3.49, p=0.001$ and between the SEL basic ( $\mathrm{Md} n=0.5)$ and control group ( $\mathrm{Md} n=-1)$ subtraction results $\mathrm{U}\left(\mathrm{N}_{\text {sembasic }} 30, \mathrm{~N}_{\text {control }} 23\right)=180, z=-3.02, p=0.003$.

There are also statistically significant differences between groups in the school climate subscale peer/adult relations $\mathrm{H}(2)=9.14, p=0.01$, however the post-hoc analysis did not show statistically significant differences between any of the three groups' results. Lastly, there are differences between the groups in the parental involvement subtraction results $H(2)=10.13$, $\mathrm{p}=0.006$. The post-hoc test indicated statistically significant differences between the SuperSEL ( $\mathrm{Md} n=0$ ) and control group ( $\mathrm{Md} n=-1$ ) subtraction results $\mathrm{U}\left(\mathrm{N}_{\text {supersem }} 32, \mathrm{~N}_{\text {control }} 26\right)=255, z=-2.56, p=0.01$ and between the SEL basic ( $\mathrm{Md} n=0$ ) and control group ( $\mathrm{Md} n=-1)$ subtraction results $\mathrm{U}\left(\mathrm{N}_{\text {sembasic }} 32, \mathrm{~N}_{\text {control }} 26\right)=227, z=-3.04, p=0.002$.

To determine differences in perceived school climate between the SEL and control groups for $3^{\text {rd }}$ - to $6^{\text {th }}$-grade students after the first year of SEL and controlling for time, the difference between the end of the first year of the SEL program (measurement no. 2) and before starting the SEL program (measurement no. 1) was calculated, and this difference was compared between the two groups (see Table 2).

The hypothesis that $3^{\text {rd }}$ - to $6^{\text {th }}$-grade SEL program students will show higher perceived school climate at the end of the first year was partially confirmed. There is no significant difference between the groups in the $3^{\text {rd }}$ - to $4^{\text {th }}$-grade student results, however there are significant differences in $5^{\text {th }}$ - to $6^{\text {th }}$-grade student results. There are statistically significant differences in the school climate subscale mental health between the results of $5^{\text {th }}$ - to $6^{\text {th }}$-grade students in the SEL and control groups $U\left(\mathrm{~N}_{\text {sem }} 94\right.$, $\left.\mathrm{N}_{\text {control }} 88\right)=3299, z=-2.38, p=0.01$, with SEL students ( $\mathrm{Md} n=-1$ ) indicating a lower number of mental health absence days than control group students $(\mathrm{Md} n=1)$. 
Table 2. Differences in school climate between SEL and control groups of $3^{\text {rd }}$ to $6^{\text {th }}$-grade students at the end of the first year of the SEL program's implementation

\begin{tabular}{|c|c|c|c|c|c|c|c|}
\hline \multirow[b]{2}{*}{ School climate } & \multicolumn{3}{|c|}{ SEL } & \multicolumn{3}{|c|}{ Control } & \multirow{2}{*}{$\boldsymbol{U}$} \\
\hline & $n$ & $M$ & $S D$ & $n$ & $M$ & $S D$ & \\
\hline $\begin{array}{l}3^{\text {rd }}-4^{\text {th }} \text { grade } s c h o o l \\
\text { climate } \\
\text { sum } 2-1\end{array}$ & 39 & 8.5 & 8.45 & 40 & 10.9 & 5.96 & 600 \\
\hline $\begin{array}{l}5^{\text {th }}-6^{\text {th }} \text { grade school } \\
\text { climate }_{\text {sum }} 2-1\end{array}$ & 79 & 1.1 & 14.9 & 72 & -3.8 & 27 & 2430 \\
\hline $\begin{array}{l}5^{\text {th }}-6^{\text {th }} \text { grade } \text { school } \\
\text { connectedness 2-1 }\end{array}$ & 98 & -0.3 & 2.57 & 89 & -0.7 & 4.58 & 4231 \\
\hline $5^{\text {th }}-6^{\text {th }}$ grade character $2-1$ & 98 & -0.9 & 3.83 & 90 & -1.4 & 4.66 & 4156 \\
\hline $\begin{array}{l}5^{\text {th }}-6^{\text {th }} \text { grade physical } \\
\text { Environment } 2-1\end{array}$ & 97 & -0.8 & 2.41 & 89 & -1.1 & 3.26 & 4221 \\
\hline $\begin{array}{l}5^{\text {th }}-6^{\text {th }} \text { grade adult support } \\
2-1\end{array}$ & 96 & -0.4 & 2.98 & 90 & -0.9 & 4.23 & 3856 \\
\hline $\begin{array}{l}5^{\text {th }}-6^{\text {th }} \text { grade peer support } \\
2-1\end{array}$ & 97 & 0 & 2.26 & 91 & -0.6 & 2.94 & 3798 \\
\hline $\begin{array}{l}5^{\text {th }}-6^{\text {th }} \text { grade cultural } \\
\text { acceptance } 2-1\end{array}$ & 95 & -0.2 & 2.89 & 89 & -0.2 & 4.46 & 4020 \\
\hline $\begin{array}{l}5^{\text {th }}-6^{\text {th }} \text { grade order and } \\
\text { discipline } 2-1\end{array}$ & 94 & -0.3 & 3.22 & 85 & -0.4 & 4 & 3966 \\
\hline $5^{\text {th }}-6^{\text {th }}$ grade safety $2-1$ & 95 & 1.3 & 3.89 & 88 & 0.8 & 4.54 & 3685 \\
\hline $\begin{array}{l}5^{\text {th }}-6^{\text {th }} \text { grade mental } \\
\text { health } 2-1\end{array}$ & 94 & -1.6 & 6.53 & 88 & 2.85 & 12.9 & $3299 * *$ \\
\hline
\end{tabular}

$* * p<0.01$

To determine the differences between the three groups of $3^{\text {rd }}$ to $6^{\text {th }}$-grade students starting their second year of SEL, a Kruskal-Wallis H test with post-hoc Mann-Whitney U test was used (see Table 3).

The hypothesis that the SuperSEL student group would show higher perceived school climate results than the SEL basic student group in the second year and that no change would be observed in the control group was partially confirmed. At the beginning of the second SEL year, there are differences within the results of $3^{\text {rd }}$ - and $4^{\text {th }}$-grade students $H(2)=15.62$, $p=0.001$, as the post-hoc analysis shows statistically significant differences between the SuperSEL ( $\mathrm{Md} n=36)$ and control group results ( $\mathrm{Md} n=33$ ) $\mathrm{U}\left(\mathrm{N}_{\text {SuperSEL }} 114, \mathrm{~N}_{\text {control }} 82\right)=3414, z=-3,23, p=0.01$ and between the SEL basic group ( $\mathrm{Md} n=36)$ and control group ( $\mathrm{Md} n=33$ ) results $\mathrm{U}\left(\mathrm{N}_{\text {SELbasic }} 127\right.$, $\left.\mathrm{N}_{\text {control }} 82\right)=3603, z=-3.77, p=0.001$. Both groups of $3^{\text {rd }}$ - to $4^{\text {th }}$-grade SEL students show equally high perceived school climate results, and there is no statistically significant difference between these results. 
Table 3. Differences in school climate between $3^{\text {rd }}$ - to $6^{\text {th }}$-grade students in SuperSEL, SEL basic and control groups starting the second year of the SEL program

\begin{tabular}{|c|c|c|c|c|c|c|c|c|c|c|}
\hline \multirow{2}{*}{$\begin{array}{l}\text { School } \\
\text { climate }\end{array}$} & \multicolumn{3}{|c|}{ SuperSEL } & \multicolumn{3}{|c|}{ SEL basic } & \multicolumn{3}{|c|}{ Control } & \multirow[t]{2}{*}{$\mathbf{H}$} \\
\hline & $n$ & $M$ & $S D$ & $n$ & $M$ & $S D$ & $n$ & $M$ & $S D$ & \\
\hline $\begin{array}{l}3^{\text {rd }}-4^{\text {th }} \\
\text { grade }^{\text {school }} \\
\text { climate }_{\text {sum }} 1\end{array}$ & 114 & 34.9 & 4.02 & 127 & 35.2 & 3.62 & 82 & 33.4 & 3.39 & $15.62^{* * *}$ \\
\hline $\begin{array}{l}5^{\text {th }}-6^{\text {th }} \\
\text { grade }^{\text {school }} \\
\text { climate }_{\text {sum }} 1\end{array}$ & 98 & 158.7 & 14.86 & 110 & 157.8 & 14.8 & 90 & 153.8 & 17.9 & 3.742 \\
\hline $\begin{array}{l}5^{\text {th }}-6^{\text {th }} \text { grade } \\
\text { school con- } \\
\text { nectedness } 1\end{array}$ & 109 & 14.9 & 2.46 & 116 & 14.7 & 2.9 & 90 & 14.3 & 2.57 & 2.736 \\
\hline $\begin{array}{l}5^{\text {th }}-6^{\text {th }} \text { grade } \\
\text { character } 1\end{array}$ & 106 & 20.6 & 2.65 & 117 & 20.2 & 2.46 & 92 & 20 & 2.95 & 2.930 \\
\hline $\begin{array}{l}5^{\text {th }}-6^{\text {th }} \text { grade } \\
\text { physical } \\
\text { environment } 1\end{array}$ & 106 & 12.4 & 2.35 & 116 & 12.77 & 2.29 & 92 & 12.5 & 2.59 & 1.763 \\
\hline $\begin{array}{l}5^{\text {th }}-6^{\text {th }} \\
\text { grade adult } \\
\text { support } 1\end{array}$ & 109 & 13 & 2.53 & 112 & 13.8 & 2.13 & 89 & 13.1 & 2.75 & $5.738^{*}$ \\
\hline $\begin{array}{l}5^{\text {th }}-6^{\text {th }} \text { grade } \\
\text { peer support } 1\end{array}$ & 109 & 10.1 & 1.59 & 117 & 9.8 & 1.69 & 92 & 9.8 & 1.6 & 4.915 \\
\hline $\begin{array}{l}5^{\text {th }}-6^{\text {th }} \\
\text { grade cultural } \\
\text { acceptance } 1\end{array}$ & 108 & 13.9 & 3.12 & 115 & 14.2 & 2.58 & 92 & 13.9 & 2.96 & 0.374 \\
\hline $\begin{array}{l}5^{\text {th }}-6^{\text {th }} \text { grade } \\
\text { order and } \\
\text { discipline } 1\end{array}$ & 106 & 14.6 & 2.78 & 116 & 15 & 2,64 & 92 & 14.2 & 3.31 & 2.512 \\
\hline $\begin{array}{l}5^{\text {th }}-6^{\text {th }} \text { grade } \\
\text { safety } 1\end{array}$ & 107 & 8 & 2.26 & 117 & 8.7 & 2.6 & 92 & 8.7 & 2.53 & 5.491 \\
\hline $\begin{array}{l}5^{\text {th }}-6^{\text {th }} \\
\text { grade mental } \\
\text { health } 1\end{array}$ & 107 & 12.9 & 5.67 & 116 & 15.8 & 8.35 & 91 & 14.7 & 9.59 & $8.084^{* * *}$ \\
\hline
\end{tabular}

$* p<0.05 ; * * p<0.01 ; * * * p<0.001$

As for the $5^{\text {th }}$ to $6^{\text {th }}$-grade student group, there were statistically significant differences between the three groups in the school climate subscale adult support $\mathrm{H}(2)=5.738, p=0.05$, however post-hoc analysis did not show significant differences between any of the groups. There were statistically significant differences between the three groups in the school climate subscale mental health $\mathrm{H}(2)=8.084, p=0.01$. The post-hoc analysis shows statistically significant differences between the SuperSEL group 
$(\mathrm{Md} n=11)$ and the control group $(\mathrm{Md} n=13)$ results $\mathrm{U}\left(\mathrm{N}_{\text {supersem }} 107\right.$, $\left.\mathrm{N}_{\text {control }} 88\right)=887, z=-2.35, p=0.01$ and between the SuperSEL group $(\mathrm{Md} n=11)$ and the SEM basic group $(\mathrm{Md} n=13)$ results $\mathrm{U}\left(\mathrm{N}_{\text {superSEM }} 107\right.$, $\left.\mathrm{N}_{\text {SEMbasic }} 116\right)=4972, p=0.01$. There were no differences between the SEL basic group and the control group results.

Table 4. Differences in school climate between SuperSEL, SEL basic and control groups of 3rd-6th-grade students at the end of the second SEL year

\begin{tabular}{|c|c|c|c|c|c|c|c|c|c|c|}
\hline \multirow{2}{*}{$\begin{array}{l}\text { School climate } \\
n\end{array}$} & \multicolumn{3}{|c|}{ SuperSEL } & \multicolumn{3}{|c|}{ SEL basic } & \multicolumn{3}{|c|}{ Control } & \multirow{2}{*}{$\mathbf{H}$} \\
\hline & $M$ & $S D$ & $n$ & $M$ & $S D$ & $n$ & $M$ & $S D$ & & \\
\hline $\begin{array}{l}3^{\text {rd }}-4^{\text {th }} \text { grade } \\
\text { School } \\
\text { climate }_{\text {sum }} 2-1\end{array}$ & 114 & 0.8 & 5 & 127 & 0.2 & 4.45 & 76 & 0.3 & 4.87 & 0.309 \\
\hline $\begin{array}{l}5^{\text {th }}-6^{\text {th }} \text { grade } \\
\text { school }_{\text {climate }_{\text {sum }} 2-1}\end{array}$ & 88 & 2 & 18.05 & 99 & 2.1 & 20.8 & 78 & 0.3 & 18.78 & 0.32 \\
\hline $\begin{array}{l}5^{\text {th }}-6^{\text {th }} \\
\text { grade school } \\
\text { connectedness } \\
2-1\end{array}$ & 101 & 0.5 & 3.12 & 108 & -0.2 & 3.77 & 80 & 0.1 & 3.14 & 2.540 \\
\hline $\begin{array}{l}5^{\text {th }}-6^{\text {th }} \text { grade } \\
\text { character } 2-1\end{array}$ & 98 & 0.4 & 3.4 & 109 & 0.1 & 3.1 & 81 & -1.2 & 3.32 & 3.006 \\
\hline $\begin{array}{l}5^{\text {th }}-6^{\text {th }} \text { grade } \\
\text { physical } \\
\text { environment 2-1 }\end{array}$ & 99 & -0.5 & 2.35 & 107 & -0.3 & 3.22 & 81 & -0.4 & 2.87 & 0.627 \\
\hline $\begin{array}{l}5^{\text {th }}-6^{\text {th }} \text { grade } \\
\text { adult } \\
\text { support } 2-1\end{array}$ & 101 & 0.3 & 2.99 & 108 & -0.3 & 3.31 & 81 & -0.6 & 3.58 & 3.654 \\
\hline $\begin{array}{l}5^{\text {th }}-6^{\text {th }} \text { grade } \\
\text { peer support } 2-1\end{array}$ & 101 & -0.4 & 1.99 & 109 & -0.6 & 2.6 & 81 & 0 & 1.92 & 1.987 \\
\hline $\begin{array}{l}5^{\text {th }}-6^{\text {th }} \\
\text { grade cultural } \\
\text { acceptance } 2-1\end{array}$ & 97 & 1.1 & 3.67 & 107 & 0 & 3.85 & 81 & 0 & 3.82 & 4.887 \\
\hline $\begin{array}{l}5^{\text {th }}-6^{\text {th }} \text { grade } \\
\text { order and } \\
\text { discipline } 2-1\end{array}$ & 98 & 0.4 & 3.02 & 108 & -0.2 & 3.54 & 81 & 0.6 & 3.59 & 3.737 \\
\hline $\begin{array}{l}5^{\text {th }}-6^{\text {th }} \text { grade } \\
\text { safety } 2-1\end{array}$ & 99 & 0.3 & 3.64 & 109 & -0.1 & 4.28 & 81 & -0.3 & 3.85 & 1.326 \\
\hline $\begin{array}{l}5^{\text {th }}-6^{\text {th }} \text { grade } \\
\text { mental health } \\
2-1\end{array}$ & 99 & -0.3 & 8.09 & 106 & -2.4 & 10.38 & 88 & -1.4 & 12.3 & 0.531 \\
\hline
\end{tabular}

$p>0.05$ 
To determine differences in perceived school climate from $3^{\text {rd }}$ to $6^{\text {th }}$-grade student groups after the second SEL year and controlling for time, the difference between the end of the second SEL year (measurement no. 2) and the beginning of the second SEL year (measurement no. 1) was calculated, and this measurement was compared across the three groups (see Table 4). In the second SEL year, the student groups were different from the first year, and therefore the measurement names were kept the same as in the first year, indicating a new set of students and new measurements.

At the end of the second SEL year, there were no differences between the three groups regarding perceived school climate.

\section{Discussion}

We hypothesized that SEL teachers would show a higher perceived school climate compared to the control group and that, in the second year of the SEL program, those teachers who received regular supervision would show higher results compared to the SEL basic training teacher group and control group. This hypothesis was partially confirmed, as it was shown that, in the first year of the SEL program's implementation, SEL teachers gave higher ratings for overall perceived school climate compared to the control group. However, in the second year, both SEL teacher groups had significantly higher perceived school climate results compared to the control group, and there is no significant difference between the SEL teacher groups. Thus, regardless of the additional regular supervision, both program interventions were effective. Both SEL groups show higher staff connectedness compared to the control group, which suggests that both the SuperSEL and SEL basic groups developed close relationships with colleagues during the SEL program and that teachers felt a strong commitment toward the school, which is in line with previous research findings showing that one aspect of SEL is better relationships with others (Weaver \& Wilding, 2013). There were also differences in the parental involvement category, where the control group's results decreased in the second year while the results remained the same for both SEL groups, which could indicate that without a conscious goal to involve parents in school life, parental involvement decreases with time (Mahoney et al., 2020). These results also demonstrate that even though the SEL program is directly aimed at children, teachers benefit from it as well, which is in line with previous research findings (Jennings \& Greenberg, 2009).

The hypothesis that students would differ in perceived school climate in the first and second years of the SEL program was partially confirmed. In the first year, students in $3^{\text {rd }}$ and $4^{\text {th }}$ grades did not show any difference 
in perceived school climate; however, students in the $5^{\text {th }}$ and $6^{\text {th }}$ grades did show a lower level of mental health problems, which is in line with other research findings (Durlak et al., 2011). At the start of the second year, $3^{\text {rd }}$ and $4^{\text {th }}$-grade students in both SEL groups showed higher perceived school climate results compared to the control group, and this difference remained the same during the whole second year, suggesting lasting changes in perceived school climate for these students. It seems that more lasting changes are first demonstrated by younger students.

Starting from the second year of the SEL program, only the $5^{\text {th }}$ - to $6^{\text {th }}$-grade SuperSEL student group showed a substantial change in perceived school climate in the mental health subscale. These results are supported by findings that state that regular support is needed to provide the best possible outcomes for students (Mahoney et al., 2020). This research also shows that the first change in perceived school climate for secondary school students is better mental health. We speculate that additional changes would be observed in other aspects of the school climate with the continuation of the program. Research shows that noticeable outcomes can first be observed three to five years after a successful SEL program implementation (Elias et al., 1997; Zins \& Elias, 2007).

These findings indicate that schools can be a place where students develop better social emotional competence, greater attachment to school, and better relationships with peers and adults. Thus, they will be more motivated to learn, have better academic results, have better mental health, and, in the long term, will be more successful in all areas of life (Durlak et al., 2011).

\section{Limitations}

The support from the SEL program's developers and school administrations was limited, and school administrations were involved in a formal way. There was only one program developer who could invest their resources in regular supervision, and there were no resources to readjust SEL materials based on schoolteachers' feedback. The lack of support for teachers during the implementation process could interfere with the program's fidelity and other aspects of a sound implementation process (Zins \& Elias, 2007).

For the further success of the SEL program and better student and teacher outcomes, more support in the implementation process should be provided. Future research should measure the implementation process in a more direct way, such as by asking teachers to evaluate the support provided in supervision sessions and then take this into account in the interpretation phase. 


\section{Conclusions}

These teacher and student results suggest that the Latvian SEL program is effective and aligned with a large body of research that shows that SEL programs are associated with a better-perceived school climate (Osher \& Berg, 2017). It can be concluded that teachers who implemented the program gained increased satisfaction with the overall perceived school climate in both SEL years. In the second year, there is significantly higher perceived staff connectedness in both SEL groups, indicating better relationships among teachers, as well as a greater attachment to the school. For students, it can be concluded that the first observable outcomes can be seen for older students in the form of better mental health. However, in order to maintain the necessary change in mental health outcomes, regular support for teachers must be provided. It seems that the primary beneficiaries of such a program are primary school students where better perceived school climate is observed at the start of the second year of the SEL program, and this better perceived school climate remained the same during the whole year.

\section{References}

Barbarasch, B., \& Elias, M. J. (2009). Fostering social competence in schools. In R. W. Christner \& R. B. Mennuti (Eds.), School-based mental health: A practitioner's guide to comparative practices (pp. 125-148). New York, NY: Routledge/Taylor \& Francis Group.

CASEL - Collaborative for Academic, Social, and Emotional Learning. (2003). Safe and sound: An educational leader's guide to evidence-based social and emotional learning (SEL) programs. Chicago, IL: Author.

CASEL. (2020). Evidence-based social and emotional learning programs: CASEL criteria updates and rationale. Chicago, IL: Author. https://casel.org/wp-content/uploads/ 2021/01/11_CASEL-Program-Criteria-Rationale.pdf done

Gilliam, W. S., \& Shahar, G. (2006). Preschool and child care expulsion and suspension: Rates and predictors in one state. Infants \& Young Children, 19(3), 228-245. https://doi. org/10.1097/00001163-200607000-00007

Denham, S., Bassett, H., \& Zinsser, K. (2012). Early childhood teachers as socializers of young children's emotional competence. Early Childhood Education Journal, 40(3), 137-143. http://eric.ed.gov/?id = EJ963274

Durlak, J. A., Weissberg, R. P., Dymnicki, A. B., Taylor, R. D., \& Schellinger, K. (2011). The impact of enhancing students' social and emotional learning: A meta-analysis of school-based universal interventions. Child Development, 82, 405-432

Elias, M. J., Zins, J. E., Weissberg, R. P., Frey, K. S., Greenberg, M. T., Haynes, N. M., Kessler, R., Schwab-Stone, M. E., \& Shriver, T. P. (1997). Promoting social and emotional learning: Guidelines for educators. Alexandria, VA: Association for Supervision and Curriculum Development. 
Greenberg, M. T., \& Domitrovich, C., Weissberg, R. \& Durlak, J. (2017). Social and emotional learning as a public health approach to education. Future of Children, 27, 13-32. 10.1353/foc.2017.0001

Jennings, P. A., \& Greenberg, M. T. (2009). The prosocial classroom: Teacher social and emotional competence in relation to student and classroom outcomes. Review of Educational Research, 79, 491-525.

Jones, S., Farrington, C. A., Jagers, R., Brackett, M., \& Kahn, J. (2019). Social, emotional, and academic development: $A$ research agenda for the next generation. National Commission on Social, Emotional, and Academic Development. Washington, DC: The Aspen Institute.

La Salle, T. P., Rocha-Neves, J., Jimerson, S., Di Sano, S., Martinsone, B., Majercakova Albertova, S., Gajdošová, E., Baye, A., Deltour, C., Martinelli, V., Raykov, M., Hatzichristou, C, Palikara, O., Éva Szabó, E., Arlauskaite, Z., Athanasiou, D., BrownEarle, O., Casale, G., Lampropoulou, A., Mikhailova, A., Pinskaya, M., \& Zvyagintsev, R. (2021). A multi-national study exploring adolescent perceptions of school climate and mental health problems. School Psychology Review, 36(3)155-166. 10.1037/spq0000430

La Salle, T. P., McIntosh, K., \& Eliason, B. M. (2016). School climate survey suite administration manual. Eugene, OR: OSEP Technical Assistance Center on Positive Behavioral Interventions and Supports University of Oregon. Done

Mahoney, J. L., Weissberg, R. P., Greenberg, M. T., Dusenbury, L., Jagers, R. J., Niemi, K., Schlinger, M., Schlund, J., Shriver, T. P., VanAusdal, K., \& Yoder, N. (2020). Systemic social and emotional learning: Promoting educational success for all preschool to high school students. American Psychologist. Advance online publication. https://doi. org/10.1037/amp0000701

Martinsone, B.. Niedre, R, Bērziña, S. (2021). Sociāli emocionālā mācīšanās. Nodarbïbu plāni 1.-12. klasei. Valsts izglìtības satura centrs | ESF projekts Nr.8.3.1.1/16/I/002 Kompetenču pieeja mācību saturā.

National School Climate Council. (2007). The School Climate Challenge: Narrowing the Gap Between School Climate Research and School Climate Policy, Practice Guidelines and Teacher education Policy. Retrieved from: http://nscc.csee.net

O'Conner, R., De Feyter, J., Carr, A., Luo, J. L., \& Romm, H. (2017). A review of the literature on social and emotional learning for students ages 3-8: Characteristics of effective social and emotional learning programs (part 1 of 4). Washington, DC: U.S. Department of Education, Institute of Education Sciences, National Center for Education Evaluation and Regional Assistance, Regional Educational Laboratory Mid-Atlantic.

Osher, D., \& Berg, J. (2017). School climate and social and emotional learning: The integration of two approaches. State College: Edna Bennet Pierce Prevention Research Center, Pennsylvania State University.

Reyes, M. R., Brackett, M. A., Rivers, S. E., White, M., \& Salovey, P. (2012). Classroom emotional climate, student engagement, and academic achievement. Journal of Educational Psychology, 104(3), 700-712. doi:10.1037/a0027268

Schonert-Reichl, K. A. (2017). Social and emotional learning and teachers. The Future of Children, 27(1), 137-155. doi:10.1353/foc.2017.0007

Thapa, A., Cohen, J., Guffey, S., \& Higgins-D'Alessandro, A. (2013). A review of school climate research. Review of Educational Research, 83(3), 357-385. doi:10.3102/ 0034654313483907

Weaver, L. \& Wilding, M. (2013). The 5 dimensions of engaged teaching. Bloomington, IN: Solution Tree Press. 
Weissberg, R. P., Durlak, J. A., Domitrovich, C. E., \& Gullotta, T. P. (2015). Social and emotional learning: Past, present, and future. In R. P. Weissberg, J. A. Durlak, C. E. Domitrovich, \& T. P. Gullotta, Handbook for social and emotional learning: Research and practice (pp. 3-19). New York: The Guildford Press.

Zins, J. \& Elias, M. (2007). Social and Emotional Learning: Promoting the Development of All Students. Journal of Educational and Psychologycal Consultation, 17, 233-255. $10.1080 / 10474410701413152$. 